\title{
Effect of fertilizer management on growth and yield of fragrant fine rice varieties in rainfed condition
}

\begin{abstract}
A field experiment was carried out at the Banglasesh Institute of Nuclear Agriculture (BINA) farm, Mymensingh during July to December 2010, to find out optimum variety and optimum fertility management of aromatic fine rice grown in transplant rainfed condition. The experiment was laid out in split-plot design with three replications assigning the variety in the main plot and different fertilizer management in the sub-plot. Results indicated that the effect of aromatic fine rice varieties and fertilizer management showed significant variation in respect of yield contributing characters and yield. At harvest, maximum number of effective tillers/hill (12.7 and 12.5), number of grains/panicle (105.6 and 115.2), 1000 grain weight (13.25 and $19.97 \mathrm{~g}$ ), grain yield (3.29 and $3.30 \mathrm{t} / \mathrm{ha})$ and straw yield (5.0 and $5.7 \mathrm{t} / \mathrm{ha}$ ) were obtained from the application of T6 (NPKSZn; RD BARC, 2005) @ 126.9, 19.81, 65, 43.3 and $1.8 \mathrm{~kg} / \mathrm{ha}+\mathrm{Cow}$ dung at $5.0 \mathrm{t} / \mathrm{ha}$ ) and T9 (Urea super granules (USG) @ 1 (1.8 g) granules/spot) + PKSZn; (RD BARC, $2005 @ 19.81,65,43.3$ and $1.8 \mathrm{~kg} / \mathrm{ha})$. The fertilizer management T6 (NPKSZn; RD BARC, 2005) @ 126.9, 19.81, 65, 43.3 and 1.8 kg/ha+Cow dung at $5.0 \mathrm{t} / \mathrm{ha}$ ) and T9 (Urea super granules (USG) @ 1 (1.8 g) granules/spot)+PKSZn; (RD BARC,2005 @ 19.81, 65, 43.3 and $1.8 \mathrm{~kg} / \mathrm{ha}$ ) produced the highest grain yield of Ukunimadhu (2.95 t/ha) and Kataribhog (3.96 t/ha).
\end{abstract}

Keyword: Fertilizer management; Fragrant fine rice; Yield; Yield attributing characters 